\title{
The colonial origins of deforestation: an institutional analysis
}

\author{
Sébastien Marchand*
}

\begin{abstract}
This paper investigates whether inherited colonial legacies influence deforestation rates in 60 former colonized developing countries. I hypothesize that differences in deforestation among countries can be attributed to their colonial legacies shaping the current impact of the institutional background on deforestation. Overall, I find that institutions defined as the extent of democracy, the quality of property rights and the quality of government functioning (e.g., corruption), have a differential impact on deforestation rates according to colonial legacies as defined by the identity of the colonizer. More precisely, I find that (1) in countries characterized by "bad" governance, former French colonies deforest relatively less than former British and Spanish colonies whereas (2) in countries characterized by "good" governance, the result is reversed. These results are robust when geography features are controlled for since the process of colonization was not random and depended on initial geographic and climatic conditions.
\end{abstract}

Keywords : Deforestation ; Institutional persistence ; Colonial legacies.

\footnotetext{
${ }^{*}$ Corresponding author. Associate professor, CERDI (Centre d'Etudes et de Recherches sur le Développement International), Université d'Auvergne; 65, Boulevard F. Mitterrand, 63000 Clermont-Ferrand, France. Email address: sebastien.marchand@udamail.fr. I would like to thank Pascale Combes Motel, Christian Ebeke, LouisMarie Philippot, Gérard Duchêne and Louis Hotte. The author thanks the multi-training program "International Governance, universalism and relativism rules and institutions: What roles for international institutions?" for financial support and the Fondation pour les Études et Recherches sur le Développement International (FERDI). This work was also supported by the Agence Nationale de la Recherche of the French government through the program "Investissements d'avenir" ANR-10-LABX-14-01.
} 


\section{Introduction}

Development economics theorists have long studied whether the colonial power's identity or colonial strategy mattered for subsequent development in previously colonized countries. For instance, recent research thought has revealed that colonialism does significantly influence development patterns and that the identity of the colonial power is also important to subsequent economic development (see Hanson (1989); Grier (1999); Bertocchi and Canova (2002)).

This paper investigates whether colonial legacies have long-term implications for deforestation rates through their lasting effect on the institutional background. This paper tries thereby to investigate how colonial legacies may affect deforestation rates in previously colonized countries by assuming that these effects could be based on current institutional performance. This paper then belongs to the literature on historical and comparative institutional analysis (HCIA) which states that the current institutional framework "is a reflection of an historical process in which past economic, political, social, and cultural features interrelate and have a lasting impact on the nature and economic implications of a society's institutions" (Greif, 1998, pp.82). Inherited legacies such as colonial legacies are thus considered as a main "indirect" factor of development, and significant in understanding how institutions shape economic or environmental performance. In turn, this literature studies the existence of institutional persistence (Acemoglu et al., 2001; Acemoglu and Johnson, 2005; Chong and Zanforlin, 2000; Lange, 2004). ${ }^{1}$

This paper investigates the role of colonial legacies through the institutional performance because the institutional background is viewed as a significant underlying cause of deforestation shaping economic incentives (Mendelsohn, 1994; Deacon, 1994; Geist and Lambin, 2002). This paper focuses on three underlying institutional causes of deforestation: (1) an overall measure of the quality of governance and a measure of the extent of democratic rules as well (civil liberties, political regime (autocratic, democratic), political liberties); (2) informal policies such as the functioning of government (e.g., the extent of corruption, government effectiveness and the quality of the government's business regulatory system); (3) the property rights regimes such as the risk of ownership, the quality of both the legal structure and the rule of law.

Thereby, this paper investigates whether moving from French to British colonial legacies may influence the deforestation and whether the quality of institutions may affect the role of colonial legacies on deforestation. For instance, to our knowledge only Novoa (2007) has investigated this

\footnotetext{
${ }^{1}$ Legacies can be legal origin of law and regulation. See La Porta et al. (2007) for a review of the Legal Origin Theory.
} 
issue and argues that former British colonies do relatively better than former Spanish colonies in terms of avoiding deforestation because former British colonies have inherited better property rights than Spanish ones.

The effects of institutional persistence on deforestation through colonial legacies are estimated on a core dataset of 61 countries which meet two conditions: (1) they are former colonies, and (2) they are not located in Europe. The second criterion excludes European countries to reflect the difficulty of classifying the colonial history of most European countries such as Italy or Finland for instance.

The main result of this paper is that the role of institutions on deforestation should be understood in the light of the particular history of each country. An improvement in the quality of institutions is more effective in dampening deforestation in countries previously colonized by Spain or Great Britain than in those colonized by France. By contrast, former French colonies tend to deforest less than former Spanish and British colonies in a context of "bad" governance. This result suggests a need to more thoroughly puzzle out the role of colonial origins in order to combat deforestation. This study argues that in a context of poor governance (such as weak property rights, corruption, autocracy, low level of government functioning), previous French colonies are relatively better than other former colonies in terms of deforestation, and suggests that the presence of some French colonial legacies have helped to preserve forests. Finally, since colonization strategies were not random and depended on geographical and climatic conditions, geographic features are controlled for. The main results remain significant and robust. ${ }^{2}$

These overall results suggest that researchers should lay emphasis on the significance of the relativism in the understanding of the effects of institutions on deforestation. ${ }^{3}$ Thereby, this paper tries to put institutional relativism in perspective and also show that the path towards institutional efficiency in order to reduce environmental damages is more complicated than we may think (Allen, 2012). Researchers should have to carefully consider the social environment before proposing recommendations in terms of institutional improvements. The institutional rules depend on constraints which are based on the social environment influenced by legacies.

The rest of the paper is organized as follow. Section 2 provides an overview of the literature on institutional persistence through colonial legacies and provides a link with deforestation. Section 3 introduces the econometric approach and Section 4 shows and discusses the main

\footnotetext{
${ }^{2}$ Results are less robust for former British colonies but overall the results suggest that colonial strategies matter in understanding the role of institutions on deforestation.

${ }^{3}$ In this paper, the notion of institutions and governance are confounded and are defined such as the incentive structure of an economy represented by legal and political rules as well as by government practises.
} 
econometric results. Section 5 provides concluding remarks and policy recommendations.

\section{Colonial legacies, institutions and deforestation}

Colonial legacies are assumed to affect early institutions which are, in turn, hypothesized to have persisted over time in order to shape the basis of current institutions influencing the current deforestation in previously colonized countries. In this section, I discuss these hypothesis through (1) a discussion regarding the nature, the emergence and the persistence of institutions, and (2) the link between deforestation and institutions.

\subsection{Institutional persistence}

Over the past few years, several studies have investigated the persistence of both political and economic institutions. These studies investigate how this persistence over time may be able to shape economic development. Before turning to the persistence of institutions, I follow North (1994) to define the nature of institutions. North (1994, p.359) notices that "institutions form the incentive structure of a society, and the political and economic institutions, in consequence, are the underlying determinants of economic performance." Thus institutions are the incentive structure created by humans and imposed on human interactions in order to determine human choices that shape the performance of societies and economies over time (North, 1990, 1994). ${ }^{4}$

In addition, institutions sustain and are sustained by shared conceptions and expectations and have also relatively durable, self-reinforcing, and persistent qualities (although they are neither immutable nor immortal) (Hodgson, 1998). Thus there is a path dependence, the aggregation of beliefs and institutions that have evolved over time and survived, since human society has inherited institutions. People start with a set of beliefs that are derived from the past so that individuals have to some degree been socialized through prior engagement with institutions. Thereby people receive information, used to make choices, that will be apprehended through the enculturation or cultural heritage faced by them and their own experience. Thus there is relations between cultural heritage, individual experience, learning and choices (North, 2006). ${ }^{5}$

\footnotetext{
${ }^{4}$ Institutions can be both formal rules (e.g., constitutions, law and property rights) and informal constraints (e.g., customs, traditions or sanctions). Appropriate institutions allow for the reduction of uncertainty in exchange and result in lower transaction and production costs. Institutions help to enhance allocative efficiency as well as the feasibility of engaging in long term economic activities such as the sustainable use of natural resources and the improvement of environmental quality (Bohn and Deacon, 2000).

${ }^{5}$ In chapters four (pages 23-37) and five (pages 38-47), North (2006) provides explanations of the creation
} 
Moreover, institution may persist over time through the cultural legacy or heritage left by the colonizer through legal origins of law and regulations (Djankov et al., 2003; La Porta et al., 2007), and by colonial strategies that depended on conditions in a given colony. For instance, according to Acemoglu et al. (2001), paths of institutional development rely on economic or political mechanisms, which explains why institutions persist over time. In this study, Acemoglu and his co-authors argue that Europeans colonizers adopted several colonization strategies with separate associated institutions depending on the conditions in colonies. As such Acemoglu et al. (2001)'s study highlights the role of colonial origins in development process through institutions and, thus, the importance of the issue of institutional persistence. The authors explain that the feasibility of European settlement, i.e., the colonization strategy, is characterized by the mortality rates of the colonizers influenced by the conditions within colonies (e.g., the disease environment and population density). Moreover the author argue that past institutions have persisted over time so that the current effects of institutions on economic development can be explained by past institutions designed by Europeans in their colonies. They demonstrate econometrically that previous "extractive colonies", which were characterized by a high level of mortality of settlers, experienced bad institutions impeding the current institutions and thus the current level of development. Unlike these extractive colonies, the "settler colonies" had good institutions brought by the colonizer, which have persisted over time, encouraging economic development in these former colonies.

Lange et al. (2006) also argue that differences between the British and Spanish colonial economic model had large consequences for the type of areas they preferred to settle, the extent of colonial institutional building they designed and thus the legacies they left after colonial independence. Spanish and British colonizers pursued different levels in their founding of colonial institutional due to endowment factors in pre-colonial areas. The Spanish mostly settled and concentrated colonial institutions in the most populous, politically and economically developed colonies at the beginning of the colonial era whereas the British limited settlement and institutional transformation in the more populous, politically and economically developed pre-colonial areas. Thereby Lange et al. (2006) find that the level of colonialism had opposite effects on long-term socio-economic development for Spanish and British colonies. More extensive British colonialism introduced an effective administration and a rule of law promoting development after independence whereas more extensive Spanish colonialism produced inefficient markets and of human perception, i.e. the process of human learning, and human beliefs from information derived from individual experience and cultural heritage, and apprehended by cognitive processes. 
predatory states leaving stratified societies after independence.

Lange (2004) also investigates the relationship between the form of colonialism and postcolonial democratization in 33 former British colonies using the general framework of Acemoglu et al. (2001) Lange (2004) focuses on two forms of dominations: an integrated or directly ruled one, and a dispersed or indirectly ruled one. He finds that the legal-administrative institutions in indirectly ruled domination, which linked the colonial administration to local people via chiefs enhancing the executive, legislative and judiciary powers of chiefs, experienced bad current institutional performances (measured by the ICRG index and the democracy index of Freedom House) as opposed to the direct ruled system based on formal rules and a structured legaladministrative system.

Also, Grier (1999) investigates the relationship between the identity of the colonizing power and current economic growth in former African colonies. He finds that former British colonies have currently better economic performance than French ones. Licht et al. (2007) study the role of cultural value on the prevalence of social institutions defined as the rule of law, control of corruption, and democratic accountability, and find both (1) a positive direct effect of British rule on governance and (2) evidences on a British heritage on governance through a cultural channel. Moreover, Olsson (2009) investigates the effect of colonial duration and time of independence on contemporary levels of democracy. He finds a positive relationship between the duration of colonial rule and current democracy, even after controlling for time of independence and the level of democracy at independence. He argues that this positive relationship is mainly driven by the experience of former British colonies and by countries colonized after 1850 during a more liberal era. In a attempt to determine when constitutional change occurs, Hayo and Voigt (2010) conclude that the colonial status matters. They find that the survival of constitutional form increases if the country was a French or British colony implying that the constitutions of colonial powers are still adequate in a post-colonial world. More recently, Jones (2012) argues that differences in colonial institutions in colonies ruled by the same colonial power matter. She proposes a new instrument - the salary of colonial governors - for measuring the quality of colonial institutions and finds evidence that colonies with higher paid governors developed better institutions (and higher per capita income) than those with lesser paid governors. 


\subsection{Institutions and deforestation}

Among the determinants of deforestation, institutions are often held to play a leading role. Since institutions are defined as the incentive structure shaping economic human interactions, they can help to move the system towards sustainable forestry management and economic development. In this sense, deforestation is viewed as the result of competing land uses between maintaining the natural forest and developing agriculture (Barbier and Burgess, 1997, 2001; Arcand et al., 2008). Agricultural conversion implies that potential timber and environmental benefits (resulting from the "keeping" forest option) are irreversibly lost and represent the "price" or the opportunity cost of agricultural conversion and deforestation. As consequence, institutions such as property rights influence the importance of opportunity costs generated by deforestation. Therefore creating appropriate institutions allows for the reduction of uncertainty in exchange and results in reduced transaction and production costs of long-term activities such as sustainable forestry. The poor quality of institutions in developing countries may thus constitute a major impediment for forest conservation.

In the literature on deforestation causes, there has been an attempt to find a relationship between deforestation and political institutions although the type of institutional variables used by authors differs. A broader view of institutions is often used in order to represent both institutional factors and policy (Geist and Lambin, 2002). ${ }^{6}$ From this broader view emerges three important determinants: (1) informal policies (e.g., corruption), (2) property rights regimes (e.g., the ownership risk), and (3) political institutions shaping both informal policies and property rights regime (e.g., the quality of the rule of law and political stability).

Firstly, informal policies are informal pro-deforestation policy. For instance, endemic corruption promotes rent seeking activities and mismanagement of forestry production which leads, in turn, to an over-extraction of resources (Amacher, 2006; Karsenty et al., 2008) (for theoretical studies, see Eerola (2004); Barbier et al. (2005); Wilson and Damania (2005); Bulte et al. (2007); Delacote (2008), and for empirical works, see Barbier and Burgess (2001); Barbier (2004); Barbier et al. (2005); Galinato and Galinato (2009)). In addition, Callister (1999); ContrerasHermosilla (2000) argue that the extent of corrupt activities in forestry is higher in the case of tropical deforestation for three main reasons. First, forest activities are often located in remote

\footnotetext{
${ }^{6}$ Policy here refers to the quality of the functioning of the government, i.e., governance. However, government policies such as macroeconomic policies, including monetary and fiscal policies, domestic and international trade policies can also have adverse effects on conservation (see for instance Anderson (1990); Arcand et al. (2008)) and use of natural resources but are not studied in this paper. Here I focus on governance in the promotion of sustainable practises particularly through sound governmental activities.
} 
areas, far away from the press, political power and the public (Hotte, 2001). Second, timber is not inventoried but only valuable so that it is very difficult to assess how much wood has been illegally extracted. Third, in developing countries, government officials are often badly paid and often have a high level of discretionary power which, combined with high valued timber-logs, favours corruption.

Secondly, the focus is made on secured property rights and deforestation (Mendelsohn (1994); Angelsen (1999); Hotte (2001) for theoretical studies and Southgate and Runge (1990); Deacon (1994, 1999); Bohn and Deacon (2000); Bhattarai and Hammig (2001); Culas (2007); Arcand et al. (2008) for empirical works). ${ }^{7}$ The role of ownership risk is particularly investigated. The main underlying hypothesis is that "poorly enforced ownership exposes standing forests and other kinds of capital to a form of confiscation or default risk and thereby discriminates against capital intensive land uses" (Deacon, 1994, p421). In addition, since deforestation is a low intensive capital extraction process, poorly defined property rights tend to lead to overextraction. In this case, the higher the risk of losing ownership, the more the discount rate and the lower future returns for forestry activities will be. Hence, an agent will prefer, for instance, to cut wood and develop non-capital intensive permanent agriculture activities rather than forestry because maintain forestry activities is heavily discounted. Put differently, sustainable harvesting of forest products is most sensitive to the existence of strong property rights. In this literature, the measurement of weak property rights differs but could be grouped into two different variables. The first are more direct indicators such as the enforceability of contracts (Culas, 2007). This indicator measures the relative degree to which contractual arrangements are honoured. The second rely upon measures of political instability such as coups, revolutions and political assassinations since insecure property rights might arise from a lack of a government's stability to enforce laws of property (Deacon, 1994, 1999; Bohn and Deacon, 2000; Arcand et al., 2008).

The third and last group of institutions is a broad notion of political institutions which determines the quality of policies implemented to preserve forest. This mainly concerns the quality of the rule of law, political stability and the extent of political and civil rights. For instance, Bhattarai and Hammig (2001) use an aggregated index of civil and political liberties taken from Freedom House to capture the role of political institutions and find a negative impact on deforestation. They argue that more democracy and freedom promote of sound

\footnotetext{
${ }^{7}$ At the local level, see for instance Godoy et al. (1997) for Bolivia and Otsuki et al. (2002); Araujo et al. (2009) for Brazil.
} 
environmental practises and better conservation of forest land in Africa and South America.

\section{Data}

\subsection{Dataset and variables}

The core dataset regroups 60 countries which were required to meet two conditions: (1) they are former colonies, (2) they are not located in Europe. ${ }^{8}$

Appendix A indicates which countries are both in the core dataset of 60 countries and in the other sub-sample. Deforestation rates have been calculated from various Forest Resources Assessment (FRA) provided by the Food and Agriculture Organization (FAO). Although forest area data have been available since 1960, only data from 1990 to 2005 is used here, given the lack of reliability of the data before the 1990-FRA. Consequently, the dependent variable is the four-year average annual rate of deforestation during the sub-periods 1990-1993, 1994-1997, 1998-2001, and 2002-2005.

The colonial origin variables are coded by the dominant colonial power over the period 1750-2009. Though for most countries the coding was relatively straightforward, it was more complicated where the country had been colonized by multiple countries. In this case, the assumption is that the most recent colonizer had had the biggest effect on institutional infrastructure at the time of independence. ${ }^{9}$ Four categories of formerly colonized countries have been created. The groups are the former colonies colonized by (i) France, (ii) England, (iii) Spanish and (iv) other countries (Belgium, the Netherlands, the Ottoman Empire, Portugal, and Spain, Japan or the U.S).

\subsection{Institutional variables}

Institutional determinants are divided into three parts (see Appendix B for more details and a complete definition of each institutional variable).

Two measures of global governance quality are firstly used. The first measure is an indicator which combines the six separate variables created by the World Bank Governance Indicators database (WBGI) into a single index. ${ }^{10}$ These variables are: control of corruption, rule of law, voice and accountability, political stability and absence of violence, government effectiveness,

\footnotetext{
${ }^{8}$ The sample used is shaped by the data for the relative price of timber, available for only 60 countries.

${ }^{9}$ Some countries were colonized by joining colonial powers, such as Cameroon, and were coded according to the colonial power of the more populous part (France in the case of Cameroon).

${ }^{10}$ See Kaufmann et al. (2008) for more details on the construction of these variables.
} 
and regulatory quality. I first reverse all of the original indicators of governance as follows:

$$
W B G I_{i}=\frac{W B G I_{i}-\min \left(W B G I_{i}\right)}{\max \left(W B G I_{i}\right)-\min \left(W B G I_{i}\right)},
$$

where $\min \left(W B G I_{i}\right)$ and $\max \left(W B G I_{i}\right)$ represent the minimum and the maximum of each indicator. This transformation implies a range between 0 and 1 . The aggregate index of governance is then the first principal component of the vector of the six indicators of governance, which accounts for $78 \%$ of the overall covariance.

The second overall measure is a measure of democracy created by the Quality of Government Institute (University of Gothenburg) from Freedom House data on civil liberties and political rights, and from the Polity 2 Index of the Polity IV project. The Freedom House data are a standardized averaged index of civil liberties (with values from 1 (the freest) to 7 (the least free)) and political rights ((with values from 1 (the freest) to 7 (the least free)). The Polity2 variable captures the regime authority spectrum on a range from -10 (hereditary monarchies) to +10 (consolidated democracy), and the three component variables that record key qualities of executive recruitment, constraints on executive authority, and political competition. The average index of democracy is then standardized as follows:

$$
\text { Democracy }_{i}=\frac{\text { Democracy }_{i}-\min \left(\text { Democracy }_{i}\right)}{\max \left(\text { Democracy }_{i}\right)-\min \left(\text { Democracy }_{i}\right)},
$$

where $\min \left(\right.$ Democracy $\left._{i}\right)$ and $\max \left(\right.$ Democracy $\left._{i}\right)$ represent the minimum and the maximum of the average index of democracy. The new variable is then transformed to a scale from 0 (autocracy) to 1 (full democracy).

The second part of institutional variables represents measures of the quality of government functioning. The composite indicator from the World Bank Indicators database is broken up to return to specific measures of quality of governance, i.e., the level of corruption, government's effectiveness, and the extent of regulatory quality.

In the third part, two indices are used to measure the quality of property rights. The first is the "Legal Structure and Security of Property Rights" index of the Fraser Institute which ranges from 0 to 1 where 0 corresponds to weak/bad legal structure. The index is a general overview of the legal structure in a country and gathers judicial independence, impartial courts, protection of property rights, military interference in the rule of law and the political process, integrity of the legal system, legal enforcement of contracts and regulatory restrictions on the 
sale of real property. The second is the Rule of Law index of the World Bank Governance Indicators database which ranges from 0 (the worst rule of law) to 1 (the best rule of law) and measures the extent to which agents have confidence in and abide by the rules of society, and in particular the quality of contract enforcement, the police and courts, and the likelihood of crime and violence as well.

However, both of these variables are a measure of legal institutions, not institutions associated specifically with property rights. Thus, an index of ownership risk is calculated following the Bohn and Deacon's approach (Bohn and Deacon, 2000). These authors used an empirical model of investment on the relationships between ownership risk and investment decisions. Since the security of property rights affects the extent of investment and the efficiency with which inputs are allocated, ownership risk could be defined as a probability of expropriation, i.e., a capture of all claims to investment projects (Djankov et al., 2003). Captures can be enacted by government, private parties, or "bad" courts. In this model, expropriation risk is empirically represented by (1) the level of government stability (revolutions; guerilla warfare; purges; political assassinations; and constitutional change), and (2) regime type (Parliamentary democracy; Non-parliamentary democracy; Strong executive; Military dictatorship; Monarchy; Others). The underlying assumption of this model are that investors "have some underlying notion of a permanent country-specific ownership risk that is better measured empirically by the long-run frequency of such events" and can "perceive risk which might rise temporarily after an event occurs" (Bohn and Deacon, 2000, p.538). These short and long run links are modeled by (1) the country-specific average frequency of each political event and (2) by dummies for the temporal occurrence of individual events in the current or preceding year. Investment is also regressed on traditional economic variables such as output per worker, human capital per worker and openness (following Bohn and Deacon (2000)). The basic equation of investment is:

$$
\text { Invest }_{i, t}=\theta_{0}+\theta_{1} G D P_{i, t-1}+\theta_{2} H_{i, t-1}+\theta_{3} \text { Open }_{i, t-1}+\theta_{4} \text { Regime }_{i, t}+\theta_{5} \text { Stability }_{i, t}+\varepsilon_{i, t}
$$

where Invest represents the investment/output ratio, GDP is the log of output per worker in $t-1, H$ represents the human capital in $t-1$, open is the degree of openness in $t-1$, regime represents the first political attributes associated to political regime, stability is the government stability and $\varepsilon_{i, t}$ is the disturbance term. 
An unbalanced panel dataset covering 60 previously colonized countries from 1990 to 2005 is used. The dependant variable is the total investment as percent of GDP. The output per worker comes from the last version of the Penn World Table (Heston et al., 2009) and the human capital variable is the ratio of secondary-school enrolment to population provided by Banks (2008). As a measure of openness, I follow Bohn and Deacon (2000) who use the sum of exports and imports divided by GDP provided by the last version of the Penn World Table (Heston et al., 2009). Political data come from the Cross-national time-series data archive of Arthur S. Banks (Banks, 2008). Political instability is measured by revolutions, political assassinations, purges, guerilla warfare and major constitutional changes. The cross-national time-series data archive provides the number of these political events but dummy variables, defined to equal one if at least one such event occurred in a given country and year, represent them in our model following Bohn and Deacon (2000). Political regimes are created using the following three criteria of Bohn and Deacon (2000): the type of chief executive (premier, president, military officer, monarch and other), the method of selection of the chief executive (direct election, indirect election, and non-elective,) and the existence or effectiveness of the legislature (effective, partially effective, ineffective, and non-existent). In turn, six political regimes have been created: (1) a parliamentary democracy with an effective or partially-effective legislature and an executive directed by a directly elected premier; (2) a non parliamentary democracy with a non-elected premier at the head of executive with an effective or partially effective legislature; (3) a strong executive regime with an ineffective or non-existent legislature; (4) a military regime; (5) a monarchy; and (6) an "other" regime category. A constitutional change variable is used in the same way as Bohn and Deacon (2000). They specify that constitutional change can have a non-linear effect on investment according to the regime type. The dummy variable representing constitutional change is then crossed with the regime type which is recorded as follows: the parliamentary and non-parliamentary democracies are gathered to create a democracy regime (called "regime D") whereas strong executive, military dictatorship, monarchy and others represent a nondemocracy regime (called "regime A"). Finally, when a constitutional change occurred during year $t$, such a variable equals one for a given country in year $t$ if, for instance, the country began year $t$ in regime D and ended it in regime A. Finally, the index of ownership risk is then constructed by country by multiplying coefficients of each political attribute, i.e., government stability and regime type, by the level of each political attribute and then adding them. The 
index ranges from 0 (high ownership risk) to 1 (low ownership risk). ${ }^{11}$

\subsection{An econometric deforestation model}

To study the role of colonial legacies on deforestation through institutional performance, interaction terms are used. Each institutional variable is crossed with each colonial dummy (British, Spanish, Other colony where the reference is French). However, although interaction terms may suggest two interpretations, inherited legacies allows for a reasonably one-way interpretation. ${ }^{12}$

Hence, the following equation was estimated to test the hypothesis that institutions affect deforestation differently according to colonial origins:

$$
\text { deforest }_{i, t}=\alpha+\delta_{1} I N S T_{i, t}+\phi_{1} I N S T * L E G_{i, t}+\phi_{2} L E G_{i}+X_{i, t}^{\prime} \beta+\nu_{r}+\eta_{t}+\epsilon_{i, t},
$$

where $i$ represent the country and $t$, the non-overlapping following 4-years periods, 19901993, 1994-1997, 1998-2001, and 2002-2005. $\nu_{r}$ and $\eta_{t}$ represent the region and period fixed effects respectively. ${ }^{13}$ Estimation results are made with the OLS estimator because the interested variables (i.e., colonial legacies) are non-varying. ${ }^{14}$ That is to say, one change in deforestation for the same time period for all countries is regressed on control variables for the same time period which are averaged over this period expect for non-varying variables and the initial level of forested areas (first year of the period).

INST is the institutional variables which are averaged over each non-overlapping 4-years period. ${ }^{15} L E G_{i}$ is the additive term or the "direct" effect of inherited legacies and $I N S T * L E G$ is the interaction term. LEG is at the same time British, Spanish and Other colonies. The strategy consists of identifying a differential effect of institutions according to colonial legacies

\footnotetext{
${ }^{11}$ The regression results of the investment model are not presented to save space but are available upon request.

${ }^{12}$ For instance, assume an interaction term between corruption (compute as high score for high corruption) and the past forested areas with a positive coefficient. There are two interpretations: (1) the higher the initial forested areas, the higher an increase in corruption raises deforestation (previous forested areas strengthen the positive effect of corruption on deforestation), (2) the higher the level of corruption (i.e., the more the corruption variable increases), the greater the scarcity effect (the positive effect of forested areas on deforestation) will be. In contract, an interaction term between corruption and a dummy coded as 1 for previously British colonies and 0 otherwise (the reference being former French colonies) would have the following interpretation: the corruption effect is less or greater in previously British colonies relative to French colonies.

${ }^{13}$ Regions are Asia, Sub-Saharan Africa, North Africa and Middle East, Latin America and Caribbean, and Oceania (only Fiji).

${ }^{14}$ Also, the random effects model cannot be used because hausman tests between the fixed (so without the colonial variables) and random models state that the fixed model is preferred to the random model (i.e., countryfixed effects are not random). Results are available upon request.

${ }^{15}$ In the regressions with the variables provided by the World Bank Governance Indicators, the data ranges from 1996 to 2005 so that the sub-periods are only 1994-1997, 1998-2001, and 2002-2005.
} 
to test the presence of institutional persistence. This strategy allows us to rank the impact of institutions on deforestation. $\delta_{1}$ captures the institutional effect in the former French colonies since legacies equal 0, i.e., when the dummies British, Spanish and Othercolonies equal 0. By contrast, $\phi_{1}$ is the institutional effect when the dummies British, Spanish and Othercolonies equal 1, i.e., the effect in former British, Spanish and other colonies relative to the former French ones. Besides, $\phi_{2}$ represents the role of colonial legacies (i.e., British, Spanish and other colonies) in a world with bad institutions $(I N S T=0) . \phi_{2}$ allows for the assumption that colonial legacies could have some effects on deforestation through other variables since inherited colonial legacies more broadly represent colonial strategies with political, economical and cultural specificities. Thus, this effect represents the consequences of colonial legacies on deforestation through channels other than institutions. The overall impact of colonial origins is thus $\phi_{1}+\phi_{2}$, and a test of the joint significance of the two coefficients is needed to validate the existence of nonlinearity due to the level of the quality of institutions.

$\mathrm{X}$ is a matrix of control variables that includes the following ${ }^{16}$ : the previous level of forested areas to control for the scarcity effect (the log of the forested area in 1990), the level of economic development (the log of the Gross Domestic Product (GDP) $)^{17}$, population growth and rural density (per $\mathrm{km}^{2}$ ) (Cropper and Griffiths, 1994), the distance from the equator (latitude) and the relative price of timber $^{18}$. See Table 1 for more details on summary statistics calculated on the entire time span, 1990-2005, and Appendix B for a detailed presentation.

[insert Table 1 here]

\section{Econometric results}

\subsection{Main results}

Table 2 to Table 4 present the results of regressions using the core dataset of countries. In all regressions, the dependent variable is the four-year average annual rate of deforestation during

\footnotetext{
${ }^{16}$ The following variable have been previously used as control variables but have been removed because they (i) have a non significant effect on deforestation and (ii) do not change the results of the institutional variables: the real effective exchange rate, the external debt, both agricultural and fuel exports, and the financial development (as the percent of domestic credit provided by banking sector).

${ }^{17}$ The GDP squared term can be introduced to test the Environmental Kuznets Curve (EKC) defining a nonlinear effect of economic growth on deforestation (Bhattarai and Hammig, 2001; Culas, 2007). The squared term is not used because the sample used is relatively homogeneous in terms of income. Results do not change with the squared term. Results available upon request.

${ }^{18}$ The relative price of timber is an important determinant in the trade-off between keeping forest or clearing it (Arcand et al., 2008).
} 
the sub-periods 1990-1993, 1994-1997, 1998-2001, and 2002-2005.

First, in Table 2, the aggregated governance index from the World Bank Governance Indicators, and the aggregated index of democracy from Freedom House and the Polity IV project are used to investigate the presence of institutional persistence on deforestation according to colonial origins. First of all, the poorer the country's governance quality or the country's index of democracy, the more deforestation in former British and Spanish colonies in comparison to former French colonies. For instance, in the case of the aggregated governance index, former British (Spanish) colonies deforest 1.7\% (3.5\%) more, on average, than former French colonies, and this difference is significant at the $1 \%$ level (column 2). Moreover, the overall impact of British and Spanish colonies is positive and significant. ${ }^{19}$ For instance, at the sample mean of the aggregated governance index, former British (Spanish) colonies deforest 0.08\% (1.7\%) more than former French colonies. ${ }^{20}$ These results mean that colonial origins matter for explaining deforestation but also that French colonial legacies seem to be relatively better at preserving forest than British and Spanish colonial legacies.

Second, I find that an improvement of institutional quality or democracy does not help to reduce deforestation in previously colonized countries (in columns 1 and 3 , the coefficient of each institutional variable is not significant). However, in columns 2 and 4, I find that institutions have a differential impact on deforestation according to their colonial origins. As such, an enhancement of democracy or the quality of institutions allows for a reduction of deforestation only in former British and Spanish colonized countries as opposed to in former French colonized countries. For instance, a shift from the median toward the 75th percentile of the distribution of the aggregated democracy index (an increase from -0.5 to -0.26 for British, and from -0.31 to -0.20 for Spanish) would lead to a decrease of the positive overall impact of the British (Spanish) legacies on deforestation from $3 \%$ to $2.5 \%$ (6.5\% to 5.8\%). These results highlight that French colonies may have inherited worse institutional features (compared to British colonies) which, in turn, does not help to dampen deforestation. More interestingly, an improvement of each institutional variable implies an increase of deforestation in former French colonies (sign of each additive variable of institutions in columns 2 and 4 ).

[insert Table 2 here]

\footnotetext{
${ }^{19}$ Table 2 reports the significance of the sum of the two coefficients associated with each colonial origin and this sum is always statistically significant in the case of former British and Spanish colonies.

${ }^{20}$ In all cases, the sample mean of the institutional variable represents alternatively the mean of the former British colonies and the former Spanish colonies sample.
} 
Table 3 presents the same regressions but uses more detailed information on the quality of government functioning such as the control of corruption, the effectiveness of government and the regulatory quality. Columns 1 and 2 report the results with the corruption variable. An improvement in the control of corruption is positively associated with low deforestation suggesting that corruption is an impediment for combating deforestation in developing countries Contreras-Hermosilla (2000). However, this effect is differential according to the colonial origin. For instance, a decrease of corruption in former Spanish colonies allows for a reduction of deforestation compared to in former French colonies. However, there is no differential impact between former British and French colonies in countries with low level of corruption but there is an impact in countries with a high level of corruption. In fact, the higher the corruption, the more deforestation there is in former British colonies compared to in former French colonies. This result also holds for former Spanish colonies. For instance, although weakly corrupted former Spanish colonies deforest 3.9\% less than former French colonies, highly corrupted former Spanish countries deforest $2.7 \%$ more than former French colonies. Moreover, the overall impact of British and Spanish colonies is still positive and significant. ${ }^{21}$ At the sample mean of the corruption index, former British (Spanish) colonies deforest 0.09\% (1.2\%) more than former French colonies.

Columns 3 and 4 report the results with the government effectiveness variable. An enhancement in the effectiveness of government functioning such as the quality of public services or the civil service or the credibility of the government's commitment to such policies is not significantly associated with low deforestation (column 3). However, this effect is differential according to the colonial origin. For instance, an improvement of the quality of the functioning of the government in both former British and Spanish colonies allows for a reduction of deforestation compared to former French colonies (column 4). However, in the case where the government effectiveness is low, deforestation is higher in former British and Spanish colonies than in former French colonies. For instance, although former British (Spanish) colonies with a high quality of government functioning deforest 2.8\% (5.5\%) less than former French colonies, former British (Spanish) colonies with a low quality of government functioning deforest 1.8\% (3\%) more than former French colonies. Moreover, the overall impact of British and Spanish colonies is still positive and significant. At the sample mean of the government effectiveness index, former British (Spanish) colonies deforest 1\% (1.1\%) more than former French colonies.

\footnotetext{
${ }^{21}$ Table 3 reports the significance of the sum of the two coefficients associated with each colonial origin and this sum is always statistically significant in the case of former British and Spanish colonies.
} 
Columns 5 and 6 report the results with the quality of the business regulatory system provided by the government. An enhancement of this index is not significantly associated with low deforestation (column 5) but this effect is differential according to the colonial origin. As in the case of government effectiveness, former British (Spanish) colonies with high level of regulation deforest $2.8 \%(6.6 \%)$ less than former French colonies whereas former British (Spanish) countries with low level of regulation deforest 2.3\% (5.1\%) more than former French colonies. Moreover, the overall impact of British and Spanish colonies is still positive and significant. At the sample mean of the regulatory quality index, former British (Spanish) colonies deforest 1\% (1.02\%) more than former French colonies. These results confirm that colonial origins matter for explaining deforestation and that French colonial legacies seem to preserve the forest relatively better than British and Spanish colonial legacies.

[insert Table 3 here]

Table 4 presents the same regressions using detailed information on the quality of property rights such as an index of ownership risk, the quality of the legal structure and the quality of the rule of law. Columns 1 and 2 report the results with the ownership risk index. A reduction in the ownership risk (an increase of the index) is not significantly associated with low deforestation (column 1). However, this effect is differential according to the colonial origin. For instance, a decrease of ownership risk allows for reduction in deforestation in both former British and Spanish colonies compared to in former French colonies (column 2). However, in countries characterized by high ownership risk, deforestation is higher in former British and Spanish colonies than in former French colonies. For instance, although former British (Spanish) colonies with a low ownership risk deforest 2.7\% (3.4\%) less than former French colonies, former British (Spanish) colonies with a high ownership risk deforest 2\% (2.4\%) more than former French colonies. Moreover, the overall impact of British and Spanish colonies is still positive and significant at the sample mean of the ownership risk index. For instance, former British (Spanish) colonies deforest 0.9\% (0.6\%) more than former French colonies.

Columns 3 and 4 report the results with the index on the quality of the legal structure taken from the Fraser Institute. The differential effect according to colonial origins hold with this variable. Former British (Spanish) countries with a high-quality legal structure deforest $3.3 \%(5 \%)$ less than former French colonies whereas former British (Spanish) countries with a low-quality legal structure deforest $0.5 \%$ (0.9\%) more than former French colonies. 
Columns 5 and 6 report the results with the rule of law index taken in the World Bank Governance Indicators database. The previous results hold. An enhancement of this index is not significantly associated with low deforestation (column 5) but this effect is differential according to the colonial origin. Former British (Spanish) colonies with a high rule of law deforest 3\% (5.9\%) less than former French colonies while former British (Spanish) colonies with a low rule of law deforest $1.9 \%(3.6 \%)$ more than former French colonies. Moreover, the overall impact of British and Spanish colonies is still positive and significant at the sample mean of the regulatory quality index. For example, former British (Spanish) colonies deforest $0.9 \%$ (1.2\%) more than former French colonies. These results confirm that colonial origins matter for explaining deforestation and that French colonial legacies seem to better preserve forest compared to British and Spanish colonial legacies.

Overall, these results suggest that the institutional effect, such as the degree of democracy, the functioning of the government or the quality of property rights, on deforestation is significantly differential according to colonial origins. In badly governed countries, there are some French colonial legacies which allow for relatively more protection of forest compared to former British and Spanish colonies. However, sound government practises, democracy and more highly protected property rights are more prone to reduce deforestation in former Spanish and British colonized countries than in French ones.

[insert Table 4 here]

\subsection{The role of geography}

Colonization was not randomly implemented by colonial powers. It was done in accord with imperial aims and relative power which varied over time and between colonial powers (Engerman and Sokoloff, 2000; Joireman, 2001; Lange, 2004).

As stated in section 2, Acemoglu et al. (2001) investigates the role of colonial strategies using settler mortality data. These figures give an indication of the extent to which a particular place was suitable for European settlement. In that study, the authors argue that European colonizers adopted different colonization strategies with correspondingly different institutions, depending on conditions in colonies. They explain that the feasibility of European settlement, characterized by the mortality rates of colonizers, determined the colonization strategy. One the one hand, former "extractive colonies" were characterized by a high level of mortality of settlers and experienced bad institutions which have impeded the quality of current institutions 
and their level of development. On the other hand, the "settler colonies" had good institutions brought by the colonizer which have persisted over time, encouraging economic development in these former colonies.

In addition, the fact is that Britain colonized all or nearly all of the most favorable countries. A mean comparison test shows that former French colonies had higher settler mortality compared to former British colonies.

Table 5 reports the regressions concerning the effects of the settlers' strategie. ${ }^{22}$ The dataset is only for former colonies for which settler mortality data is available. The sample varies from 39 to 53 countries according to the choice of the institutional variable. The results concerning the differential impact of French colonial legacies compared to British and Spanish ones are identical. For instance, in former Spanish colonies with bad governance (coefficient of the additive "Spanish" variable), deforestation is significantly higher than in former French colonies with bad governance. The result concerning former British colonies is less obvious and holds only for the aggregated governance index, the democracy index, and the three property rights index. Concerning the differential impact of institutions, results hold for former Spanish colonies. The better a country's quality of governance in former Spanish colonies, the lower deforestation in comparison with former French colonies. However, the result is more mitigated in the case of former British colonies. The negative effect of an improvement of the quality of institutions on deforestation in former British colonies (compared to former French colonies) is significant only for the democracy and the legal structure indices. These results could suggest that the institutional differential impact of French colonial legacies compared to former British ones are better attributed to colonial strategies, captured by the settlers mortality variable. Incidentally, the higher the level of settler's mortality was, the higher deforestation is today. This result suggests that colonial strategies have an impact on deforestation, and that this is not attributable to the identity of the colonizer or the current influence of institutions.

Finally, the overall impact of British and Spanish colonies on deforestation is still positive and significant at the sample mean of each institutional variable. These results confirm that the colonial origins matter for explaining deforestation, and that French colonial legacies seem to be relatively better at preserving the forest compared to British and Spanish colonial legacies.

[insert Table 5 here]

\footnotetext{
${ }^{22}$ Acemoglu et al. (2001) provide data for sixty-two former colonies with the maximum settler mortality for Mali.
} 


\section{Conclusion}

Differences in institutions, defined as social and political controls on human life, may explain differences in current social, political and economic performance. This paper attempts to analyse the role of these institutional differences on deforestation in developing countries.

The main underlying theoretical hypothesis is that these differential effects of institutions can be explained by institutional persistence. As suggested by the literature on institutional persistence, legal, political and economic legacies had drawn the previous set of institutions in a country shaping the current institutional performance. Colonial legacies represent some of these legacies and are studied in this paper since they are exogenous characteristics. Put differently, this study tries to understand if institutions could have a differential impact on deforestation according to colonial legacies.

The main result of this paper is that the role of institutions on deforestation must be understood in the light of the history, including colonial legacies, of each country . For instance, improvement of the quality of institutions is more effective in reducing deforestation in countries previously colonized by Spain or Great Britain compared to those colonized by France.

In contrast, Former French colonies tend to deforest less than former Spanish and British colonies in a context of bad governance. This result suggests a need to more thoroughly puzzle out the role of colonial origins for combating deforestation. This study proposes that, in a context of poor governance (such as poor property rights, corruption, autocracy, low level of government functioning), previous French colonies are relatively better than other former colonies, and suggests, in turn, the presence of some French colonial legacies helping to preserve the forest.

As a conclusion, it is worth noting that colonial origins seem to matter in understanding the role of institutions in reducing deforestation in previously colonized countries. This study highlights the role of path dependency in which the past helps to understand the present, here through the influence of the incentive structure characterized by institutions North (2006).

Policy recommendations in terms of an improvement of institutions should take into account the fact that constraints that condition institutional rules institutions matter and that these constraints depend on legacies.

At last, this research can be extended to explain more precisely why an improvement of institutions is relatively less efficient on reducing deforestation in former French colonies than 
in British and Spanish colonies. ${ }^{23}$

\section{References}

Acemoglu, D., Johnson, S., 2005. Unbundling institutions. Journal of Political Economy 113 (5), 949-995.

Acemoglu, D., Johnson, S., Robinson, J., 2001. The colonial origins of comparative development: An empirical investigation. American Economic Review 91 (5), 1369-1401.

Acemoglu, D., Johnson, S., Robinson, J. A., 2000. The colonial origins of comparative development: An empirical investigation. Working Paper Series (7771).

Allen, D. W., 2012. The Institutional Revolution. University of Chicago Press.

Amacher, G. S., 2006. Corruption: A challenge for economists interested in forest policy design. Journal of Forest Economics 12 (2), 85 - 89.

Anderson, A., 1990. Smokestacks in the rainforest: Industrial development and deforestation in the amazon basin. World Development 18 (9), 1191-1205.

Angelsen, A., 1999. Agricultural expansion and deforestation: modelling the impact of population, market forces and property rights. Journal of Development Economics 58, 185-218.

Araujo, C., Bonjean, C. A., Combes, J.-L., Motel, P. C., Reis, E. J., 2009. Property rights and deforestation in the brazilian amazon. Ecological Economics 68 (8-9), 2461 - 2468.

Arcand, J.-L., Guillaumont, P., Jeanneney-Guillaumont, S., 2008. Deforestation and the real exchange rate. Journal of Development Economics 86 (2), 242-262.

Banks, A. S., 2008. Cross-national time-series data archive. Center for Social Analysis. Binghampton, NY: State University of New-York.

Barbier, E., Burgess, J., 1997. The economics of tropical forest land use options. Land Economics $73(2), 174-195$.

Barbier, E., Damania, R., Leonard, D., 2005. Corruption, trade and resource conversion. Journal of Environmental Economics and Management 50 (2), 276-299.

\footnotetext{
${ }^{23}$ In some cases, improvement of institutions increases deforestation contrary to theoretical arguments which argue that a better incentive structure must increase opportunity costs related to pro-deforestation activities and thus promote sustainable activities.
} 
Barbier, E. B., 2004. Explaining agricultural land expansion and deforestation in developing countries. American Journal of Agricultural Economics 86 (5), 1347-1353.

Barbier, E. B., Burgess, J. C., 2001. The economics of tropical deforestation. Journal of Economic Surveys 15 (3), 413-33.

Bertocchi, G., Canova, F., 2002. Did colonization matter for growth?: An empirical exploration into the historical causes of africa's underdevelopment. European Economic Review 46 (10), $1851-1871$.

Bhattarai, M., Hammig, M., 2001. Institutions and the environment kuznets curve for deforestation: A crosscountry analysis for latin america, africa and asia. World Development 29 (6), $995-1010$.

Bohn, H., Deacon, R. T., 2000. Ownership, investment and the use of natural resources. American Economic Review 90 (3), 526-549.

Bulte, E. H., Damania, R., Lopez, R., 2007. On the gains of committing to inefficiency: Corruption, deforestation and low land productivity in latin america. Journal of Environmental Economics and Management 54 (3), 277-295.

Callister, D., 1999. Corrupt and illegal activities in the forestry sector: Current understandings, and implications for world bank forest policy: Draft for discussion. World Bank, Washington.

Chong, A., Zanforlin, L., 2000. Law tradition and institutional quality: some empirical evidence. Journal of International Development 12 (8), 1057-1068.

Contreras-Hermosilla, A., 2000. The underlying causes of forest decline. CIFOR Occasional Paper No. 30., Bogor, Indonesia.

Cropper, M., Griffiths, C., 1994. The interaction of population growth and environmental quality. The American Economic Review 84 (2), 250-254.

Culas, R. J., 2007. Deforestation and the environmental kuznets curve: An institutional perspective. Ecological Economics 61 (2-3), 429 - 437.

Deacon, R. T., 1994. Deforestation and the rule of law in a cross-section of countries. Land Economics Vol. 70,No. 4, pp. 414-430. 
Deacon, R. T., 1999. Deforestation and ownership: Evidence from historical accounts and contemporary data. Land Economics 71 (3), 526-549.

Delacote, P., 2008. Systemic corruption, scale effects and forest harvesting. Working Paper, LEF-INRA.

Djankov, S., Glaeser, E., La Porta, R., Lopez-de Silanes, F., Shleifer, A., 2003. The new comparative economics. Journal of comparative economics 31 (4), 595-619.

Eerola, E., 2004. Forest conservation- too much or too little? a political economy model. Environmental and Resource Economics 27 (4), 391-407.

Engerman, S. L., Sokoloff, K. L., 2000. History lessons: Institutions, factors endowments, and paths of development in the new world. The Journal of Economic Perspectives 14 (3), 217-232.

Galinato, G., Galinato, S., 2009. Governance and deforestation due to agricultural land expansion. Working Paper Series WP 2009-21, School of Economic Sciences, Washington State University.

Geist, H., Lambin, E., 2002. Proximate causes and underlying driving forces of tropical deforestation. BioScience BioScience, 143-50.

Godoy, R., ONeill, K., Groff, S., Kostishack, P., Cubas, A., Demmer, J., McSweeney, K., Overman, J., Wilkie, D., Brokaw, N., Martinez, M., 1997. Household determinants of deforestation by Amerindians in Honduras. World Development 25 (6), 977-987.

Greif, A., 1998. Historical and comparative institutional analysis. The American Economic Review 88 (2), 80-84.

Grier, R. M., 1999. Colonial legacies and economic growth. Public Choice 98 (3/4), 317-335.

Hanson, J., 1989. Education, economic development, and technology transfer: A colonial test. The Journal of Economic History 49 (04), 939-957.

Hayo, B., Voigt, S., 2010. Determinants of constitutional change: Why do countries change their form of government? Journal of Comparative Economics 38 (3), 283 - 305.

Heston, A., Summers, R., Aten, B., 2009. Penn world table version 6.3, center for International Comparisons of Production, Income and Prices at the University of Pennsylvania. 
Hodgson, G. M., 1998. The approach of institutional economics. Journal of Economic Literature $36(1), 166-192$.

Hotte, L., 2001. Conflicts Over Property Rights and Natural Resource Exploitation at the Frontier. Journal of Development Economics 66, 1-21.

Joireman, S. F., 2001. Inherited legal systems and effective rule of law: Africa and the colonial legacy. The Journal of Modern African Studies 39 (4), 571-596.

Jones, P., 2012. History matters: New evidence on the long run impact of colonial rule on institutions. Journal of Comparative Economics In Press.

Karsenty, A., Drigo, I. G., Piketty, M.-G., Singer, B., 2008. Regulating industrial forest concessions in central africa and south america. Forest Ecology and Management 256 (7), 1498 1508.

Kaufmann, D., Kraay, A., Mastruzzi, M., 2008. Governance matters viii: Aggregate and individual governance indicators 1996-2008. World Bank Policy Research Working Paper Series (4978).

La Porta, R., Lopez-de Silanes, F., Shleifer, A., 2007. The economic consequences of legal origins. Journal of Economic Literature 46 (2), 285-332.

La Porta, R., Lopez-de Silanes, F., Shleifer, A., Vishny, R., April 1999. The quality of government. Journal of Law, Economics and Organization 15 (1), 222-79.

Lange, M., Mahoney, J., vom Hau, M., 2006. Colonialism and development: A comparative analysis of spanish and british colonies. American Journal of Sociology 11 (5), 1412-62.

Lange, M. K., 2004. British colonial legacies and political development. World Development $32(6), 905-922$.

Licht, A. N., Goldschmidt, C., Schwartz, S. H., 2007. Culture rules: The foundations of the rule of law and other norms of governance. Journal of Comparative Economics 35 (4), 659 - 688.

Mendelsohn, R., 1994. Property rights and tropical deforestation. Oxford Economic Papers 46, $750-56$.

North, D. C., 1990. Institutions, Institutional Change and Economic Performance. W.W.Norton, New York. 
North, D. C., 1994. Economic performance through time. American Economic Review 84 (3), $359-68$.

North, D. C., 2006. Understanding the process of economic change. Princeton University Press.

Novoa, D. C., 2007. Deforestation and property rights: A comparison between former british and spanish colonies. Economic Analysis Working Papers 7 (7).

Olsson, O., 2009. On the democratic legacy of colonialism. Journal of Comparative Economics 37 (4), 534-551.

Otsuki, T., Hardie, I., Reis, E., 2002. The implication of property rights for joint agriculturetimber productivity in the Brazilian Amazon. Environment and development economics 7 (Part 2), 299-323.

Southgate, D., Runge, C. F., 1990. The institutional origins of deforestation in latin america. Staff paper no. P90-5.

Wilson, J. K., Damania, R., 2005. Corruption, political competition and environmental policy. Journal of Environmental Economics and Management 49 (3), 516 - 535. 


\section{Tables inserted in the paper}

Table 1: Summary statistics (1990-2005)

\begin{tabular}{llllll}
\hline \multicolumn{1}{c}{ VARIABLES } & Mean & Std. Dev. & Min. & Max. & N countries \\
\hline $\begin{array}{l}\text { Deforestation (mean annual } \\
\text { rate) }\end{array}$ & 0.01 & 0.01 & -0.04 & 0.03 & 60 \\
Forest Area in 1990 (log) & 9.35 & 1.31 & 6.9 & 13.13 & 60 \\
GDP per capita (log) & 6.7 & 1.14 & 4.69 & 8.88 & 60 \\
Rural density (per km $\left.{ }^{2}\right)$ & 347.57 & 361.9 & 14.73 & 2137.18 & 60 \\
Pop. growth (\%) & 2.14 & 0.71 & 0.05 & 3.5 & 60 \\
Timber (price ratio) & 1.01 & 0.14 & 0.70 & 1.34 & 60 \\
Former French colonies & 0.3 & 0.46 & 0 & 1 & 60 \\
Former British colonies & 0.32 & 0.47 & 0 & 1 & 60 \\
Former Spanish colonies & 0.25 & 0.44 & 0 & 1 & 60 \\
Former Other colonies & 0.13 & 0.34 & 0 & 1 & 60 \\
Latitude (absolute value: 0 to & 0.16 & 0.1 & 0 & 0.38 & 60 \\
1) & & & & 7.99 & 53 \\
Settlers' mortality (log) & 4.9 & 1.09 & 2.43 & 0.79 & 60 \\
Aggregated governance index & 0.41 & 0.14 & 0.04 & 0.77 & 60 \\
Corruption WBGI & 0.37 & 0.13 & 0.09 & 0.68 & 60 \\
Government effectiv. WBGI & 0.36 & 0.11 & 0.08 & 0.9 & 60 \\
Regulatory quality WBGI & 0.57 & 0.13 & 0.19 & 0.81 & 60 \\
Rule of law WBGI & 0.4 & 0.14 & 0.07 & 0.83 & 60 \\
Accountability WBGI & 0.45 & 0.19 & 0.05 & 0.84 & 60 \\
Political stability WBGI & 0.52 & 0.17 & 0.09 & 0.65 & 54 \\
Legal structure index FI & 0.37 & 0.13 & 0.08 & 0.97 & 60 \\
Democracy index (FH-Polity 2) & 0.58 & 0.23 & 0.08 & 0.88 & 60 \\
Ownership risk (calculated in- & 0.5 & 0.16 & 0.16 & & \\
dex) & & & & \\
\hline
\end{tabular}

Table 2: Colonial origins, governance quality and deforestation

\begin{tabular}{|c|c|c|c|c|}
\hline \multirow{3}{*}{$\begin{array}{c}\text { Dependent variable: Rate of deforestation } \\
\text { VARIABLES }\end{array}$} & \multirow{2}{*}{\multicolumn{2}{|c|}{ Aggregated index WBGI }} & \multirow{2}{*}{\multicolumn{2}{|c|}{ Democracy index }} \\
\hline & & & & \\
\hline & (1) & (2) & (3) & (4) \\
\hline Former British colonies & $\begin{array}{l}0.01^{* * *} \\
(0.002)\end{array}$ & $\begin{array}{l}0.017^{* * *} \\
(0.006)\end{array}$ & $\begin{array}{l}0.009^{* * *} \\
(0.002)\end{array}$ & $\begin{array}{l}0.019^{* * *} \\
(0.003)\end{array}$ \\
\hline Former Spanish colonies & $\begin{array}{l}0.007^{* *} \\
(0.003)\end{array}$ & $\begin{array}{l}0.035^{* * *} \\
(0.007)\end{array}$ & $\begin{array}{l}0.006^{* *} \\
(0.003)\end{array}$ & $\begin{array}{l}0.048^{* * *} \\
(0.009)\end{array}$ \\
\hline Former other colonies & $\begin{array}{l}0.005^{*} \\
(0.003)\end{array}$ & $\begin{array}{l}-.002 \\
(0.005)\end{array}$ & $\begin{array}{l}0.005^{* *} \\
(0.002)\end{array}$ & $\begin{array}{l}0.004 \\
(0.005)\end{array}$ \\
\hline Institutions & $\begin{array}{l}-.007 \\
(0.006)\end{array}$ & $\begin{array}{l}0.01 \\
(0.011)\end{array}$ & $\begin{array}{l}0.004 \\
(0.004)\end{array}$ & $\begin{array}{l}0.018^{* * *} \\
(0.005)\end{array}$ \\
\hline Institutions*British & & $\begin{array}{l}-.021 \\
(0.014)\end{array}$ & & $\begin{array}{l}-.022^{* * *} \\
(0.006)\end{array}$ \\
\hline Institutions*Spanish & & $\begin{array}{l}-.053^{* * *} \\
(0.016)\end{array}$ & & $\begin{array}{l}-.054^{* * *} \\
(0.012)\end{array}$ \\
\hline Institutions*Other col. & & $\begin{array}{l}0.028^{*} \\
(0.014)\end{array}$ & & $\begin{array}{l}0.0003 \\
(0.009)\end{array}$ \\
\hline Lag Forest Area (log) & $\begin{array}{l}-.001 \\
(0.0009)\end{array}$ & $\begin{array}{l}-.001 \\
(0.0008)\end{array}$ & $\begin{array}{l}-.0007 \\
(0.0008)\end{array}$ & $\begin{array}{l}-.001 \\
(0.0007)\end{array}$ \\
\hline GDP (log) & $\begin{array}{l}-.002^{*} \\
(0.0009)\end{array}$ & $\begin{array}{l}-.001^{*} \\
(0.0008)\end{array}$ & $\begin{array}{l}-.003^{* * *} \\
(0.0007)\end{array}$ & $\begin{array}{l}-.002^{* * *} \\
(0.0007)\end{array}$ \\
\hline Rural density (per km²) & $\begin{array}{l}-7.98 \mathrm{e}-06^{* * *} \\
(2.47 \mathrm{e}-06)\end{array}$ & $\begin{array}{l}-6.14 \mathrm{e}-06^{* * *} \\
(2.28 \mathrm{e}-06)\end{array}$ & $\begin{array}{l}-7.84 \mathrm{e}-06^{* * *} \\
(2.36 \mathrm{e}-06)\end{array}$ & $\begin{array}{l}-6.99 \mathrm{e}-06^{* * *} \\
(2.16 \mathrm{e}-06)\end{array}$ \\
\hline Pop. growth & $\begin{array}{l}0.005^{* * *} \\
(0.002)\end{array}$ & $\begin{array}{l}0.004^{* * *} \\
(0.002)\end{array}$ & $\begin{array}{l}0.006^{* * *} \\
(0.002)\end{array}$ & $\begin{array}{l}0.005^{* * *} \\
(0.001)\end{array}$ \\
\hline
\end{tabular}




\begin{tabular}{lllll} 
Timber (price ratio) & 0.002 & 0.002 & 0.002 & 0.001 \\
& $(0.003)$ & $(0.003)$ & $(0.003)$ & $\begin{array}{l}(0.003) \\
\text { Latitude }\end{array}$ \\
& $-.019^{* *}$ & $-.014^{*}$ & $-.024^{* * *}$ & $-.022^{* * *}$ \\
Intercept & $(0.008)$ & $(0.008)$ & $(0.007)$ & $(0.007)$ \\
& $0.024^{* *}$ & 0.016 & $0.019^{*}$ & 0.015 \\
\hline Number of countries & $(0.012)$ & $(0.011)$ & $(0.01)$ & $(0.01)$ \\
Observations & 59 & 59 & 61 & 61 \\
Adjusted R2 & 176 & 176 & 240 & 240 \\
F-stat & 0.257 & 0.348 & 0.274 & 0.349 \\
RMSE & 6.972 & 7.367 & 9.839 & 11.676 \\
F-stat British & 0.01 & 0.009 & 0.01 & 0.009 \\
F-stat Spanish & & $9.38^{* * *}$ & & $18.02^{* * *}$ \\
\hline Note: OLS & & $16.63^{* * *}$ & & $14.79^{* * *}$ \\
\hline
\end{tabular}

Note: OLS robust standard errors in parentheses. In all regressions, regional and year dummies are introduced (omitted region is Asia). The omitted colonial origin is the formerFrench colony. Columns 1 and 2 report results with the overall aggregated index, and columns 3 and 4 report results with an aggregated index of democracy from Freedom House and Polity 2. F-stat British (Spanish) reports the F-stat and the associated significance of the following test: $\mathrm{H} 0: \phi_{1}+\phi_{2}=0 .{ }^{* * *}$ statistical significance at $1 \%,{ }^{* *}$ statistical significance at $5 \%, *$ statistical significance at $10 \%$. 
Table 3: Colonial origins, government functioning and deforestation

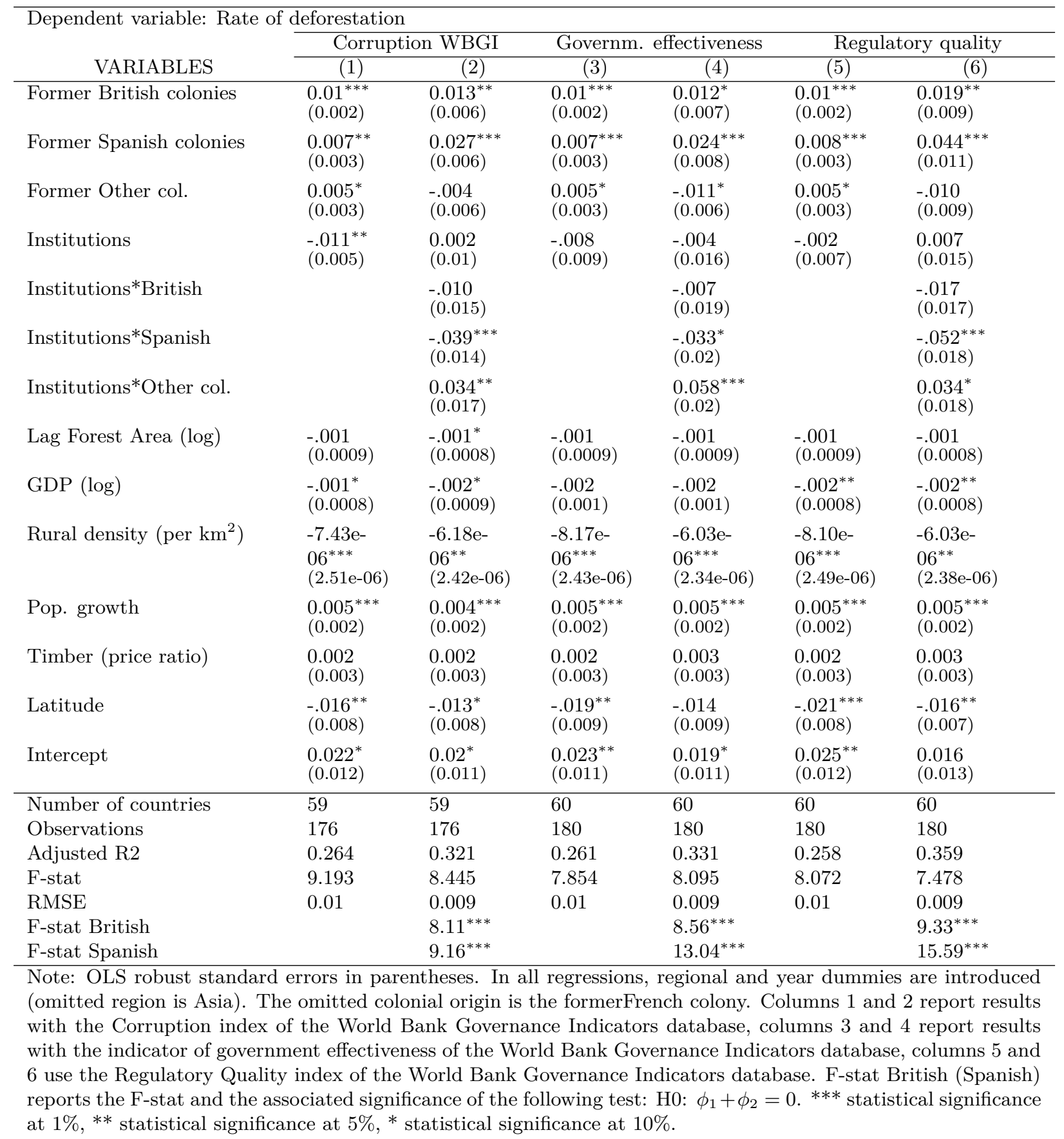


Table 4: Colonial origins, property rights and deforestation

\begin{tabular}{|c|c|c|c|c|c|c|}
\hline \multicolumn{7}{|c|}{ Dependent variable: Rate of deforestation } \\
\hline \multirow[b]{2}{*}{ VARIABLES } & \multicolumn{2}{|c|}{ Ownership risk index } & \multicolumn{2}{|c|}{ Fraser Institute index } & \multicolumn{2}{|c|}{ Rule of law index WBGI } \\
\hline & (1) & (2) & (3) & (4) & (5) & (6) \\
\hline Former British colonies & $\begin{array}{c}0.01^{* * *} \\
(0.002)\end{array}$ & $\begin{array}{c}0.019^{* * *} \\
(0.006)\end{array}$ & $\begin{array}{c}0.007^{* * *} \\
(0.002)\end{array}$ & $\begin{array}{c}0.017^{* * *} \\
(0.005)\end{array}$ & $\begin{array}{c}0.01^{* * *} \\
(0.002)\end{array}$ & $\begin{array}{c}0.016^{* * *} \\
(0.005)\end{array}$ \\
\hline Former Spanish colonies & $\begin{array}{c}0.006^{* *} \\
(0.003)\end{array}$ & $\begin{array}{c}0.022^{* *} \\
(0.009)\end{array}$ & $\begin{array}{l}0.005^{*} \\
(0.003)\end{array}$ & $\begin{array}{c}0.025^{* * *} \\
(0.004)\end{array}$ & $\begin{array}{c}0.007^{* *} \\
(0.003)\end{array}$ & $\begin{array}{c}0.032^{* * *} \\
(0.006)\end{array}$ \\
\hline Former other colonies & $\begin{array}{c}0.005^{* *} \\
(0.002)\end{array}$ & $\begin{array}{r}-.016^{* *} \\
(0.007)\end{array}$ & $\begin{array}{c}0.005 \\
(0.003)\end{array}$ & $\begin{array}{l}-.0003 \\
(0.005)\end{array}$ & $\begin{array}{l}0.005^{*} \\
(0.003)\end{array}$ & $\begin{array}{l}-.007^{*} \\
(0.004)\end{array}$ \\
\hline Institutions & $\begin{array}{l}0.0007 \\
(0.005)\end{array}$ & $\begin{array}{l}0.009 \\
(0.01)\end{array}$ & $\begin{array}{l}-.006 \\
(0.004)\end{array}$ & $\begin{array}{c}0.018^{* *} \\
(0.008)\end{array}$ & $\begin{array}{l}-.006 \\
(0.005)\end{array}$ & $\begin{array}{l}0.008 \\
(0.01)\end{array}$ \\
\hline Institutions*British & & $\begin{array}{l}-.019 \\
(0.012)\end{array}$ & & $\begin{array}{c}-.027^{* * *} \\
(0.01)\end{array}$ & & $\begin{array}{l}-.016 \\
(0.014)\end{array}$ \\
\hline Institutions*Spanish & & $\begin{array}{l}-.028^{*} \\
(0.015)\end{array}$ & & $\begin{array}{c}-.044^{* * * *} \\
(0.011)\end{array}$ & & $\begin{array}{c}-.046^{* * *} \\
(0.014)\end{array}$ \\
\hline Institutions*Other col. & & $\begin{array}{c}0.038^{* * *} \\
(0.014)\end{array}$ & & $\begin{array}{c}0.034^{* *} \\
(0.015)\end{array}$ & & $\begin{array}{c}0.047^{* * *} \\
(0.015)\end{array}$ \\
\hline Lag Forest Area (log) & $\begin{array}{l}-.0008 \\
(0.0008)\end{array}$ & $\begin{array}{l}-.0001 \\
(0.0008)\end{array}$ & $\begin{array}{l}-.0006 \\
(0.0009)\end{array}$ & $\begin{array}{c}-.001 \\
(0.0008)\end{array}$ & $\begin{array}{c}-.001 \\
(0.0009)\end{array}$ & $\begin{array}{l}-.001^{*} \\
(0.0007)\end{array}$ \\
\hline GDP (log) & $\begin{array}{c}-.002^{* * *} \\
(0.0007)\end{array}$ & $\begin{array}{l}-.003^{* * *} \\
(0.0007)\end{array}$ & $\begin{array}{c}-.002^{* * *} \\
(0.0008)\end{array}$ & $\begin{array}{c}-.002^{* * *} \\
(0.0007)\end{array}$ & $\begin{array}{l}-.002^{* *} \\
(0.0008)\end{array}$ & $\begin{array}{l}-.002^{* *} \\
(0.0008)\end{array}$ \\
\hline Rural density (per km²) & $\begin{array}{c}-7.60 \mathrm{e}-06^{* * *} \\
(2.50 \mathrm{e}-06)\end{array}$ & $\begin{array}{c}-4.49 \mathrm{e}-06^{*} \\
(2.52 \mathrm{e}-06)\end{array}$ & $\begin{array}{c}-6.63 \mathrm{e}-06^{* * *} \\
(2.24 \mathrm{e}-06)\end{array}$ & $\begin{array}{c}-5.11 \mathrm{e}-06^{* *} \\
(1.98 \mathrm{e}-06)\end{array}$ & $\begin{array}{c}-8.19 \mathrm{e}-06^{* * *} \\
(2.45 \mathrm{e}-06)\end{array}$ & $\begin{array}{c}-5.80 \mathrm{e}-06^{* *} \\
(2.27 \mathrm{e}-06)\end{array}$ \\
\hline Pop. growth & $\begin{array}{c}0.006^{* * *} \\
(0.002)\end{array}$ & $\begin{array}{c}0.006^{* * *} \\
(0.002)\end{array}$ & $\begin{array}{c}0.005^{* * *} \\
(0.002)\end{array}$ & $\begin{array}{c}0.005^{* * *} \\
(0.002)\end{array}$ & $\begin{array}{c}0.005^{* * *} \\
(0.002)\end{array}$ & $\begin{array}{c}0.004^{* * *} \\
(0.002)\end{array}$ \\
\hline Timber (price ratio) & $\begin{array}{c}0.002 \\
(0.003)\end{array}$ & $\begin{array}{c}0.002 \\
(0.003)\end{array}$ & $\begin{array}{c}0.001 \\
(0.003)\end{array}$ & $\begin{array}{l}0.0007 \\
(0.003)\end{array}$ & $\begin{array}{c}0.002 \\
(0.003)\end{array}$ & $\begin{array}{c}0.002 \\
(0.003)\end{array}$ \\
\hline Latitude & $\begin{array}{c}-.022^{* * *} \\
(0.007)\end{array}$ & $\begin{array}{c}-.021^{* * *} \\
(0.007)\end{array}$ & $\begin{array}{r}-.015^{* *} \\
(0.007)\end{array}$ & $\begin{array}{l}-.012^{*} \\
(0.006)\end{array}$ & $\begin{array}{r}-.020^{* *} \\
(0.008)\end{array}$ & $\begin{array}{l}-.013^{*} \\
(0.007)\end{array}$ \\
\hline Intercept & $\begin{array}{l}0.018^{*} \\
(0.011)\end{array}$ & $\begin{array}{c}0.009 \\
(0.012)\end{array}$ & $\begin{array}{l}0.023^{*} \\
(0.012)\end{array}$ & $\begin{array}{c}0.02 \\
(0.013)\end{array}$ & $\begin{array}{c}0.025^{* *} \\
(0.011)\end{array}$ & $\begin{array}{c}0.02^{* *} \\
(0.01)\end{array}$ \\
\hline Number of countries & 60 & 60 & 52 & 52 & 60 & 60 \\
\hline Observations & 240 & 240 & 208 & 208 & 180 & 180 \\
\hline Adjusted R2 & 0.27 & 0.325 & 0.277 & 0.359 & 0.261 & 0.375 \\
\hline F-stat & 9.498 & 8.146 & 7.668 & 10.995 & 8.212 & 9.389 \\
\hline RMSE & 0.01 & 0.009 & 0.01 & 0.009 & 0.01 & 0.009 \\
\hline F-stat British & & $16.17^{* * *}$ & & $7.10^{* * *}$ & & $9.08^{* * *}$ \\
\hline F-stat Spanish & & $4.68^{* * *}$ & & $19.72^{* * *}$ & & $21.37^{* * *}$ \\
\hline
\end{tabular}

Note: OLS robust standard errors in parentheses. In all regressions, regional and year dummies are introduced (omitted region is Asia). The omitted colonial origin is the formerFrench colony. Columns 1 and 2 report results with the inverse of the ownership risk calculated index, columns 3 and 4 report results with the legal structure and property rights index of the Fraser Institute, and columns 5 and 6 report results with the Rule of Law index of the World Bank Governance Indicators database. F-stat British (Spanish) reports the F-stat and the associated significance of the following test: $\mathrm{H} 0: \phi_{1}+\phi_{2}=0 .{ }^{* * *}$ statistical significance at $1 \%,{ }^{*}$ statistical significance at $5 \%, *$ statistical significance at $10 \%$. 
Table 5: Settler mortality, colonial origins, institutions and deforestation

\begin{tabular}{|c|c|c|c|c|c|c|c|c|}
\hline \multicolumn{9}{|c|}{ Dependent var.: Rate of deforestation } \\
\hline & $\begin{array}{l}\text { Aggregated } \\
\text { index }\end{array}$ & Democracy & Corruption & Government effectiv. & Regulatory quality & Ownership risk & Legal structure & Rule of law \\
\hline VARIABLES & $(1)$ & $(2)$ & (3) & (4) & $(5)$ & $(6)$ & $(7)$ & $(8)$ \\
\hline British colonies & $\begin{array}{l}0.012^{* *} \\
(0.006)\end{array}$ & $\begin{array}{l}0.017^{* * *} \\
(0.003)\end{array}$ & $\begin{array}{l}0.009 \\
(0.006)\end{array}$ & $\begin{array}{l}0.007 \\
(0.007)\end{array}$ & $\begin{array}{l}0.006 \\
(0.01)\end{array}$ & $\begin{array}{l}0.015^{* *} \\
(0.007)\end{array}$ & $\begin{array}{l}0.018^{* * *} \\
(0.005)\end{array}$ & $\begin{array}{l}0.012^{* *} \\
(0.006)\end{array}$ \\
\hline Spanish colonies & $\begin{array}{l}0.031^{* * *} \\
(0.008)\end{array}$ & $\begin{array}{l}0.043^{* * *} \\
(0.009)\end{array}$ & $\begin{array}{l}0.022^{* * *} \\
(0.006)\end{array}$ & $\begin{array}{l}0.022^{* * *} \\
(0.008)\end{array}$ & $\begin{array}{l}0.039^{* * *} \\
(0.011)\end{array}$ & $\begin{array}{l}0.019^{*} \\
(0.01)\end{array}$ & $\begin{array}{l}0.022^{* * *} \\
(0.004)\end{array}$ & $\begin{array}{l}0.03^{* * *} \\
(0.006)\end{array}$ \\
\hline Other colonies & $\begin{array}{l}-.002 \\
(0.005)\end{array}$ & $\begin{array}{l}0.006 \\
(0.005)\end{array}$ & $\begin{array}{l}-.003 \\
(0.006)\end{array}$ & $\begin{array}{l}-.010 \\
(0.006)\end{array}$ & $\begin{array}{l}-.008 \\
(0.009)\end{array}$ & $\begin{array}{l}-.011 \\
(0.007)\end{array}$ & $\begin{array}{l}-.002 \\
(0.005)\end{array}$ & $\begin{array}{l}-.004 \\
(0.004)\end{array}$ \\
\hline Institutions & $\begin{array}{l}0.005 \\
(0.013)\end{array}$ & $\begin{array}{l}0.013^{* *} \\
(0.005)\end{array}$ & -.004 & $\begin{array}{l}-.0004 \\
(0.017)\end{array}$ & $\begin{array}{l}0.003 \\
(0.016)\end{array}$ & $\begin{array}{l}0.005 \\
(0.01)\end{array}$ & $\begin{array}{l}0.017^{*} \\
(0.009)\end{array}$ & $\begin{array}{l}0.007 \\
(0.01)\end{array}$ \\
\hline Institutions*British & $\begin{array}{l}-.004 \\
(0.015)\end{array}$ & $\begin{array}{l}-.015^{* *} \\
(0.007)\end{array}$ & $\begin{array}{l}0.007 \\
(0.016)\end{array}$ & $\begin{array}{l}0.01 \\
(0.019)\end{array}$ & $\begin{array}{l}0.008 \\
(0.019)\end{array}$ & $\begin{array}{l}-.009 \\
(0.015)\end{array}$ & $\begin{array}{l}-.029^{* * *} \\
(0.011)\end{array}$ & $\begin{array}{l}-.003 \\
(0.016)\end{array}$ \\
\hline Institutions*Spanish & $\begin{array}{l}\text { h-. } 045^{* * *} \\
(0.016)\end{array}$ & $\begin{array}{l}-.049^{* * *} \\
(0.012)\end{array}$ & $\begin{array}{l}-.030^{* *} \\
(0.015)\end{array}$ & $\begin{array}{l}-.030 \\
(0.02)\end{array}$ & $\begin{array}{l}-.045^{* *} \\
(0.018)\end{array}$ & $\begin{array}{l}-.022 \\
(0.017)\end{array}$ & $\begin{array}{l}-.039^{* * *} \\
(0.011)\end{array}$ & $\begin{array}{l}-.042^{* * *} \\
(0.014)\end{array}$ \\
\hline \multirow{2}{*}{$\begin{array}{l}\text { Institutions*Other } \\
\text { col. }\end{array}$} & $0.029^{* *}$ & -.002 & $0.033^{* *}$ & $0.058^{* * *}$ & $0.03^{*}$ & $0.03^{*}$ & $0.03^{* *}$ & $0.042^{* * *}$ \\
\hline & $(0.014)$ & $(0.009)$ & $(0.015)$ & $(0.019)$ & $(0.018)$ & $(0.015)$ & $(0.013)$ & $(0.015)$ \\
\hline \multirow{2}{*}{$\begin{array}{l}\text { Lag Forest Area } \\
(\log )\end{array}$} & -.001 & -.001 & -.001 & -.0009 & -.0007 & -.0003 & -.001 & $-.001^{*}$ \\
\hline & $(0.0008)$ & $(0.0007)$ & $(0.0008)$ & $(0.0009)$ & $(0.0009)$ & $(0.0009)$ & $(0.0009)$ & $(0.0008)$ \\
\hline GDP (log) & $\begin{array}{l}-.001 \\
(0.0009)\end{array}$ & $\begin{array}{l}-.002^{* *} \\
(0.0008)\end{array}$ & $\begin{array}{l}-.002 \\
(0.001)\end{array}$ & $\begin{array}{l}-.002^{* *} \\
(0.001)\end{array}$ & $\begin{array}{l}-.002^{* *} \\
(0.0009)\end{array}$ & $\begin{array}{l}-.003^{* * *} \\
(0.0009)\end{array}$ & $\begin{array}{l}-.003^{* * *} \\
(0.001)\end{array}$ & $\begin{array}{l}-.002^{* *} \\
(0.0009)\end{array}$ \\
\hline \multirow{2}{*}{$\begin{array}{l}\text { Rural density } \\
\left(\text { per } \mathrm{km}^{2}\right)\end{array}$} & $-6.24 \mathrm{e}-06^{* *}$ & $-7.72 \mathrm{e}-06^{* * *}$ & $-6.29 \mathrm{e}-06^{* *}$ & $-5.56 \mathrm{e}-06^{* *}$ & $-6.13 \mathrm{e}-06^{* *}$ & $-6.05 \mathrm{e}-06^{*}$ & $-5.78 \mathrm{e}-06^{* * *}$ & $-6.03 \mathrm{e}-06^{* *}$ \\
\hline & $(2.49 \mathrm{e}-06)$ & $(2.33 \mathrm{e}-06)$ & $(2.62 \mathrm{e}-06)$ & $(2.60 \mathrm{e}-06)$ & $(2.60 \mathrm{e}-06)$ & $(3.11 \mathrm{e}-06)$ & $(2.23 \mathrm{e}-06)$ & $(2.50 \mathrm{e}-06)$ \\
\hline Pop. growth & $\begin{array}{l}0.005^{* * *} \\
(0.002)\end{array}$ & $\begin{array}{l}0.005^{* * *} \\
(0.002)\end{array}$ & $\begin{array}{l}0.005^{* * *} \\
(0.002)\end{array}$ & $\begin{array}{l}0.005^{* * *} \\
(0.002)\end{array}$ & $\begin{array}{l}0.006^{* * *} \\
(0.002)\end{array}$ & $\begin{array}{l}0.006^{* * *} \\
(0.002)\end{array}$ & $\begin{array}{l}0.006^{* * *} \\
(0.002)\end{array}$ & $\begin{array}{l}0.005^{* * *} \\
(0.002)\end{array}$ \\
\hline \multirow{2}{*}{$\begin{array}{l}\text { Timber (price ra- } \\
\text { tio) }\end{array}$} & 0.001 & 0.002 & 0.001 & 0.0005 & 0.001 & 0.003 & 0.002 & 0.0002 \\
\hline & $(0.003)$ & $(0.003)$ & $(0.003)$ & $(0.004)$ & $(0.003)$ & $(0.003)$ & $(0.003)$ & $(0.003)$ \\
\hline Latitude & $\begin{array}{l}-.013 \\
(0.008)\end{array}$ & $\begin{array}{l}-.024^{* * *} \\
(0.008)\end{array}$ & $\begin{array}{l}-.014^{*} \\
(0.008)\end{array}$ & $\begin{array}{l}-.015 \\
(0.01)\end{array}$ & $\begin{array}{l}-.015^{*} \\
(0.008)\end{array}$ & $\begin{array}{l}-.027^{* * *} \\
(0.008)\end{array}$ & $\begin{array}{l}-.018^{* *} \\
(0.007)\end{array}$ & $\begin{array}{l}-.013^{*} \\
(0.008)\end{array}$ \\
\hline \multirow{2}{*}{$\begin{array}{l}\text { Settlers mortal- } \\
\text { ity (log) }\end{array}$} & $0.003^{* * *}$ & $0.003^{* * *}$ & $0.003^{* * *}$ & $0.003^{* * *}$ & $0.003^{* * *}$ & $0.002^{* *}$ & $0.002^{*}$ & $0.003^{* * *}$ \\
\hline & $(0.001)$ & $(0.0009)$ & $(0.001)$ & $(0.001)$ & $(0.001)$ & $(0.001)$ & $(0.001)$ & $(0.001)$ \\
\hline Intercept & $\begin{array}{l}-.001 \\
(0.013)\end{array}$ & $\begin{array}{l}-.002 \\
(0.012)\end{array}$ & $\begin{array}{l}0.001 \\
(0.013)\end{array}$ & $\begin{array}{l}0.004 \\
(0.014)\end{array}$ & $\begin{array}{l}-.002 \\
(0.014)\end{array}$ & $\begin{array}{l}0.0003 \\
(0.013)\end{array}$ & $\begin{array}{l}0.009 \\
(0.016)\end{array}$ & $\begin{array}{l}0.003 \\
(0.013)\end{array}$ \\
\hline
\end{tabular}




\begin{tabular}{llllllll} 
Observations & 155 & 212 & 155 & 159 & 159 & 212 & 184 \\
Adjusted R2 & 0.38 & 0.374 & 0.363 & 0.369 & 0.386 & 0.334 & 0.39 \\
F-stat & 6.807 & 10.298 & 6.509 & 8.11 & 7.599 & 0.135 & 0.194 \\
RMSE & 0.009 & 0.009 & 0.009 & 0.009 & 0.009 & 0.009 \\
F-stat British & $10.10^{* * *}$ & $20.03^{* * *}$ & $10.33^{* * *}$ & $8.21^{* * *}$ & $8.98^{* * *}$ & $12.20^{* * *}$ & $7.38^{* * *}$ \\
F-stat Spanish & $12.65^{* * *}$ & $12.35^{* * *}$ & $9.45^{* * *}$ & $7.43^{* * *}$ & $10.91^{* * *}$ & 0.009 \\
\hline
\end{tabular}

Note: OLS robust standard errors in parentheses. In all regressions, regional and year dummies are introduced (omitted region is Asia). The omitted colonial origin is the formerFrench colony. Column 1 reports results with the overall aggregated index, column 2 with an aggregated index of democracy from Freedom House and Polity 2 , column 3 with the Corruption index of the World Bank Governance Indicators database, column 4 with the indicator of government effectiveness of the World Bank Governance Indicators database, columns 5 uses the Regulatory Quality index of the World Bank Governance Indicators database, column 6 reports results with the inverse of the ownership risk calculated index, column 7 reports results with the legal structure and property rights index of the Fraser Institute, and column 8 reports results with the Rule of Law index of the World Bank Governance Indicators database. F-stat British (Spanish) reports the F-stat and the associated significance of the following test: H0: $\phi_{1}+\phi_{2}=0 .{ }^{* * *}$ statistical significance at $1 \%$, $* *$ statistical significance at $5 \%,{ }^{*}$ statistical significance at $10 \%$. 


\title{
Appendix A List of 60 countries
}

\author{
Former 18 French Colonies \\ Algeria, Benin, Burkina Faso, Cameroon, Central African Republic, Chad, Congo Republic, Ivory Coast, \\ Dominican Republic, Gabon, Guinea, Laos, Madagascar, Mali, Morocco, Niger, Senegal, Vietnam \\ Former 19 British Colonies \\ Botswana, Fiji, Ghana, Guyana, India, Kenya, Malawi, Malaysia, Namibia, Nepal, Nigeria, Pakistan, \\ Papua New Guinea, Sierra Leone, South Africa, Sri Lanka, Sudan, Uganda, Zimbabwe \\ Former 15 Spanish Colonies \\ Argentina, Bolivia, Chile, Colombia, Costa Rica, Ecuador, Guatemala, Honduras, Mexico, Nicaragua, \\ Panama, Paraguay, Peru, Uruguay, Venezuela \\ Former 8 other Colonies \\ Angola, Brazil, Congo Democratic Republic, Guinea-Bissau, Indonesia, Mozambique, Philippines, \\ Suriname
}




\section{Appendix B Variables descriptions}

\begin{tabular}{|c|c|}
\hline Code & Variables and Definition \\
\hline Deforestation rate & Log forested areas in $t-1$ minus log forested areas in $t$. \\
\hline $\operatorname{Lag}\left(\right.$ Forest $_{t-1}$ in $\left.\log \right)$ & $\begin{array}{l}\text { Initial Forest Areas: } \log \text { forested areas calculated as the level of } \\
\text { forested areas in the first year of each non-overlapping } 4 \text {-years pe- } \\
\text { riod (e.g., } 1990 \text { for the period 1990-1993). }\end{array}$ \\
\hline GDP (log) & Log GDP per capita, constant $2000 \mathrm{US} \$$. \\
\hline Pop. growth & Annual population growth rate (percentage). \\
\hline Rural density & Rural population density per $\mathrm{km}^{2}$ of arable land. \\
\hline Timber & $\begin{array}{l}\text { The relative price of timber: the ratio of the price of hardwood logs in } \\
\text { Sarawak, Malaysia (in } \$ U \mathrm{US} / \mathrm{m} 3 \text {, source: IMF, International Financial } \\
\text { Statistics) to the country-specific unit export values of agricultural } \\
\text { goods (source: FAO) }\end{array}$ \\
\hline Colonial origins & $\begin{array}{l}\text { Colonial dummies indicating whether a country had been a British, } \\
\text { French, Spanish, or other (German, Italian, Belgian, Dutch or Por- } \\
\text { tuguese) colony. }\end{array}$ \\
\hline Mortality & $\begin{array}{l}\text { Log of the fourth mortality estimated by (Acemoglu et al., 2000, Ap- } \\
\text { pendix, Table A2). }\end{array}$ \\
\hline Latitude & $\begin{array}{l}\text { Absolute value of the latitude of the country (i.e., a measure of dis- } \\
\text { tance from the equator), scaled to take values between } 0 \text { and } 1 \text {, where } \\
0 \text { is the equator. }\end{array}$ \\
\hline Corruption WBGI & $\begin{array}{l}\text { Control of Corruption: capturing perceptions of the extent to which } \\
\text { public power is exercised for private gain, including both petty and } \\
\text { grand forms of corruption, as well as "capture" of the state by elites } \\
\text { and private interests. }\end{array}$ \\
\hline $\begin{array}{l}\text { Government effec- } \\
\text { tiveness WBGI }\end{array}$ & $\begin{array}{l}\text { Government Effectiveness: capturing perceptions of the quality of } \\
\text { public services, the quality of the civil service and the degree of its } \\
\text { independence from political pressures, the quality of policy formu- } \\
\text { lation and implementation, and the credibility of the government's } \\
\text { commitment to such policies. }\end{array}$ \\
\hline $\begin{array}{l}\text { Regulatory quality } \\
\text { WBGI }\end{array}$ & $\begin{array}{l}\text { Regulatory Quality: capturing perceptions of the ability of the gov- } \\
\text { ernment to formulate and implement sound policies and regulations } \\
\text { that permit and promote private sector development. }\end{array}$ \\
\hline Rule of law WBGI & $\begin{array}{l}\text { Rule of Law: capturing perceptions of the extent to which agents have } \\
\text { confidence in and abide by the rules of society, and in particular the } \\
\text { quality of contract enforcement, property rights, the police, and the } \\
\text { courts, as well as the likelihood of crime and violence. }\end{array}$ \\
\hline Accountability & Voice and Accountability: capturing perceptions of the extent to \\
\hline WBGI & $\begin{array}{l}\text { which a country's citizens are able to participate in selecting their } \\
\text { government, as well as freedom of expression, freedom of association, } \\
\text { and a free media. }\end{array}$ \\
\hline $\begin{array}{l}\text { Political stability } \\
\text { WBGI }\end{array}$ & $\begin{array}{l}\text { Political Stability and Absence of Violence: capturing perceptions of } \\
\text { the likelihood that the government will be destabilized or overthrown } \\
\text { by unconstitutional or violent means, including politically-motivated } \\
\text { violence and terrorism. }\end{array}$ \\
\hline Civil liberties FH & $\begin{array}{l}\text { Civil liberties allow for the freedoms of expression and belief, associ- } \\
\text { ational and organizational rights, rule of law, and personal autonomy } \\
\text { without interference from the state. }\end{array}$ \\
\hline Political rights $\mathrm{FH}$ & $\begin{array}{l}\text { Political rights enable people to participate freely in the political pro- } \\
\text { cess, including the right to vote freely for distinct alternatives in le- } \\
\text { gitimate elections, compete for public office, join political parties and } \\
\text { organizations, and elect representatives who have a decisive impact } \\
\text { on public policies and are accountable to the electorate. }\end{array}$ \\
\hline Polity 2 & $\begin{array}{l}\text { The "Polity Score" captures the regime authority spectrum on a } 21- \\
\text { point scale ranging from }-10 \text { (hereditary monarchy) to }+10 \text { (consoli- } \\
\text { dated democracy). }\end{array}$ \\
\hline Legal structure FI & $\begin{array}{l}\text { The index consists of judicial independence, impartial courts, protec- } \\
\text { tion of intellectual property, military interference in rule of law and } \\
\text { the political process, integrity of the legal system. The higher score } \\
\text { corresponds to "high judicial independence", "trusted legal framework } \\
\text { exists", "protection of intellectual property", "no military interference } \\
\text { in rule of law", and "integrity of the legal system". }\end{array}$ \\
\hline
\end{tabular}

Source

FAO

FAO

WDI 2008

WDI 2008

WDI 2008

FAODATA/IFS-IMF

La Porta et al. (1999)

Acemoglu et al. (2001)

La Porta et al. (1999)

WBGI

WBGI

WBGI

WBGI

WBGI

WBGI

Freedom House

Freedom House

Polity IV project

Fraser Institute 
Ownership risk (cal- The index is an ownership risk index calculated from an econometric culated index)

investment model with political attributes following Bohn and Deacon

Author's calculation. (2000).

NB: All time-varying variables are averaged over each non-overlapping 4-years period (1990-1993, 1994-1997, 19982001, and 2002-2005). 